\title{
The Mechanism of Speciation and Evolutionary Trend in Solanum nigrum complex ${ }^{1}$
}

\author{
M. Z. Beg and A. H. Khan \\ Department of Botany, Aligarh Muslim University, Aligarh-202001, India
}

Accepted February 28, 1987

The family Solanaceae is one of the largest bicarpellate families having 75 genera and more than 2500 species (D'Arcy, 1974). The genus Solanum which belongs to the tribe Solanae is one of the largest genera in plant kingdom being represented by approximately 2000 species (Gbile 1979).

The genus Solanum has world wide distribution with a major centre of development in Central and South America. The species of this genus are mainly classified into two groups, namely tuberiferous and non-tuberiferous. The tuberiferous species have attracted the attention of cytogeneticists and plant breeders from time to time because of their great economic importance (Magoon et al. 1962). Comparatively little attention has been paid to the cytogenetics, hybridization and reproduction of non-tuberiferous species of this group. Nontuberiferous species in general and Solanum nigrum complex in particular are also of much economic importance specially from medicinal point of view. This complex consists of several species which show similarity among themselves and differ from other species of the genus to justify their inclusion in $S$. nigrum complex. The species $S$. nigrum has three cytotypes known as diploid $(2 n=24)$, tetraploid $(2 n=48)$ and hexaploid $(2 n=72)$. This has been the matter of investigation in past to determine whether the three cytotypes constitute one or three different species.

The most taxonomically perplexing type of plant group is the polyploid complex (Stebbins 1938). In such a complex species have mostly common morphological features besides the closely similar genomes. The species hybridize freely among themselves and produce fertile hybrids. The polyploids, as a rule are derived from their relatives with lower chromosome numbers. Once the suspected ancestral species has been identified, the hypothetical evolutionary course of hybridization and chromosome doubling can be repeated and hypothesis can be subjected to the experimental verification. Keeping this aim the hexaploid form has been synthesized from triploid hybrids and its comparison and breeding behaviour with natural Indian hexaploid form of $S$. nigrum has been made. The present investigation thus deals with the probable course of mechanism of evolution of Indian hexaploid S. nigrum.

\section{Materials and method}

Diploid and hexaploid forms of $S$. niqrum and $S$. villosum ssp. puniceum were used in the present investigation. The seeds of Indian diploid and hexaploid $S$. nigrum were collected from local populations while the seeds of $S$. villosum ssp. puniceum were obtained from Dr. J. M. Edmonds, Cu. Botany School, University of Cambridge, England.

Reciprocal cross pollinations were made between $S$. villosum ssp. puniceum and Indian diploid S. nigrum. Meiosis was studied in squashes of pollen mother cells fixed in Carnoy's fluid and made permanent with butyl alcohol series (Swaminathan et al. 1954, Bhaduri and Ghosh 1954). The triploid hybrids obtained from the above mentioned cross were treated

1 Part of the Thesis submitted to the Aligarh Muslim University Aligarh, India. 
with 0.2 per cent aquous solution of colchicine and the resulting synthesized hexaploids were compared statistically with Indian hexaploid $S$. nigrum.

\section{Results}

\section{Morphology of the parents}

Consistent differences are found in morphological characters of $S$. villosum ssp. puniceum and diploid $S$. nigrum (Table 1 and Fig. 1.) The two species differ from each other in several morphological characters. The most important characters by which the two can be distinguished from each other are the colour of berry and chromosome number. In $S$. villosum ssp.

Table 1. Comparison of mean values of morphological characters of $S$. villosum ssp. puniceum, diploid $S$. nigrum and their $F_{1}$ hybrids

\begin{tabular}{|c|c|c|c|}
\hline Characters & $\begin{array}{l}\text { S. villosum ssp. } \\
\text { puniceum }\end{array}$ & Diploid $S$. nigrum & $F_{1}$ hybrids \\
\hline Habit & Erect and branched & Erect and branched & $\begin{array}{l}\text { Erect and much } \\
\text { kranched }\end{array}$ \\
\hline Height $(\mathrm{cm})$ & $62.0(55-70)$ & $76.2(70.5-80.0)$ & $10.4(88.5-120.0)$ \\
\hline Stem & $\begin{array}{l}\text { Cylindrical, redish } \\
\text { black with smooth } \\
\text { ridges }\end{array}$ & $\begin{array}{l}\text { Dark green without } \\
\text { prominent ribs }\end{array}$ & $\begin{array}{l}\text { Cylindrical, redish } \\
\text { green with prominent } \\
\text { ribs }\end{array}$ \\
\hline Leaf & $\begin{array}{l}\text { Thin, ovate to } \\
\text { elliptic with dentate } \\
\text { margin }\end{array}$ & $\begin{array}{l}\text { Thick and ovate } \\
\text { with entire or wavy } \\
\text { margin }\end{array}$ & $\begin{array}{l}\text { Thick, ovate to } \\
\text { elliptic with slightly } \\
\text { dentate margin }\end{array}$ \\
\hline Length of petioles $(\mathrm{cm})$ & $1.88(1.0-3.0)$ & $1.92(1.3-2.7)$ & $1.60(1.1-2.5)$ \\
\hline Length of lamina $(\mathrm{cm})$ & $4.07(3.2-5.2)$ & $5.11(3.2-6.5)$ & $4.91(3.4-6.5)$ \\
\hline Breadth of lamina $(\mathrm{cm})$ & $2.99(2.4-4.5)$ & $2.99(1.5-4.0)$ & $3.29(2.30-4.60)$ \\
\hline Diameter of corolla $(\mathrm{cm})$ & $1.07(0.8-1.2)$ & $0.73(0.6-0.9)$ & $1.09(0.8-1.3)$ \\
\hline Length of gynoecium (mm) & $4.67(4.0-5.0)$ & $3.98(3.0-5.0)$ & $4.22(4.0-5.0)$ \\
\hline Length of anther (mm) & $1.81(1.5-2.0)$ & $1.62(1.5-2.0)$ & $1.65(1.5-2.0)$ \\
\hline Breadth of anther (mm) & $0.91(0.75-1.00)$ & $0.72(0.5-1.0)$ & $0.55(0.5-1.0)$ \\
\hline No. of flowers per inflorescence & $5.28(3-9)$ & $4.76(3-8)$ & $4.73(3-6)$ \\
\hline No. of fruits per inflorescence & $4.07(3-5)$ & $3.65(2-5)$ & - \\
\hline Diameter of fruit (mm) & $7.03(6-8)$ & $6.50(4-8)$ & - \\
\hline No. of seeds per fruit & $32.21(24-40)$ & $35.51(30-55)$ & - \\
\hline Colour of fruit & Orange red & Shiny bluish black & - \\
\hline Thickness of leaf $(\mu)$ & $54.8 \quad(52.8-59.84)$ & $59.84(49.28-70.4)$ & $65.75(52.8-77.44)$ \\
\hline Pollen fertility $(\%)$ & 98.40 & 92.58 & 1.07 \\
\hline Pollen size $(\mu)$ & $24.74(17.6-28.16)$ & $19.82(17.6-21.12)$ & $28.58(21.12-31.68)$ \\
\hline No. of stomata per area & $16.67(13-21)$ & $28.68(26-33)$ & $25.60(21-30)$ \\
\hline No. of epidermal cells per area & $35.04(29-40)$ & $50.21(45-55)$ & $48.32(41-54)$ \\
\hline Length of guard cell $(\mu)$ & $34.92(29.92-45.76)$ & $24.12(17.6-35.2)$ & $26.56(21.12-33.44)$ \\
\hline Breadth of guard cell $(\mu)$ & $21.99(19.36-24.64)$ & $18.09(12.32-24.64)$ & $19.07(15.84-22.88)$ \\
\hline Length of stomatal aperture $(\mu)$ & $23.38(17.6-31.68)$ & $16.76(10.56-24.64)$ & $16.45(10.56-21.12)$ \\
\hline Breadth of stomatal aperture $(\mu)$ & $8.01(5.28-10.56)$ & $6.81(3.52-14.08)$ & $6.77(3.52-8.8)$ \\
\hline Gametic chromosome number (n) & 24 & 12 & 18 \\
\hline
\end{tabular}

puniceum the berries are orange red whereas in diploid $S$. nigrum they are shiny bluish black. The gametic chromosome number in former is 24 whereas in the latter it is 12 . A statistical comparison of mean values of several vegetative and floral characters between two population showed significant differences in most of the morphological characters (Table 2) except length of petiole, length of stomatal aperture and breadth of anther. S. villosum spp. puniceum showed higher mean values over diploid $S$. nigrum in length and breadth of guard cell, length and breadth of stomatal aperture, diameter of corolla, length of gynoecium, length and breadth of anther and number of flowers and fruits per inflorescence. However, diploid S. nigrum 
showed higher mean values over $S$. villosum ssp. puniceum in height of plants, length of petiole, length of lamina, number of stomata and epidermal cells per unit area.

\section{Hybridization}

The crosses were successful only when $S$. villosum ssp. puniceum $(2 n=48)$ was taken as female parent and diploid $S$. nigrum $(2 \mathrm{n}=24)$ as male parent. Fifty flower buds of $S$. villosum

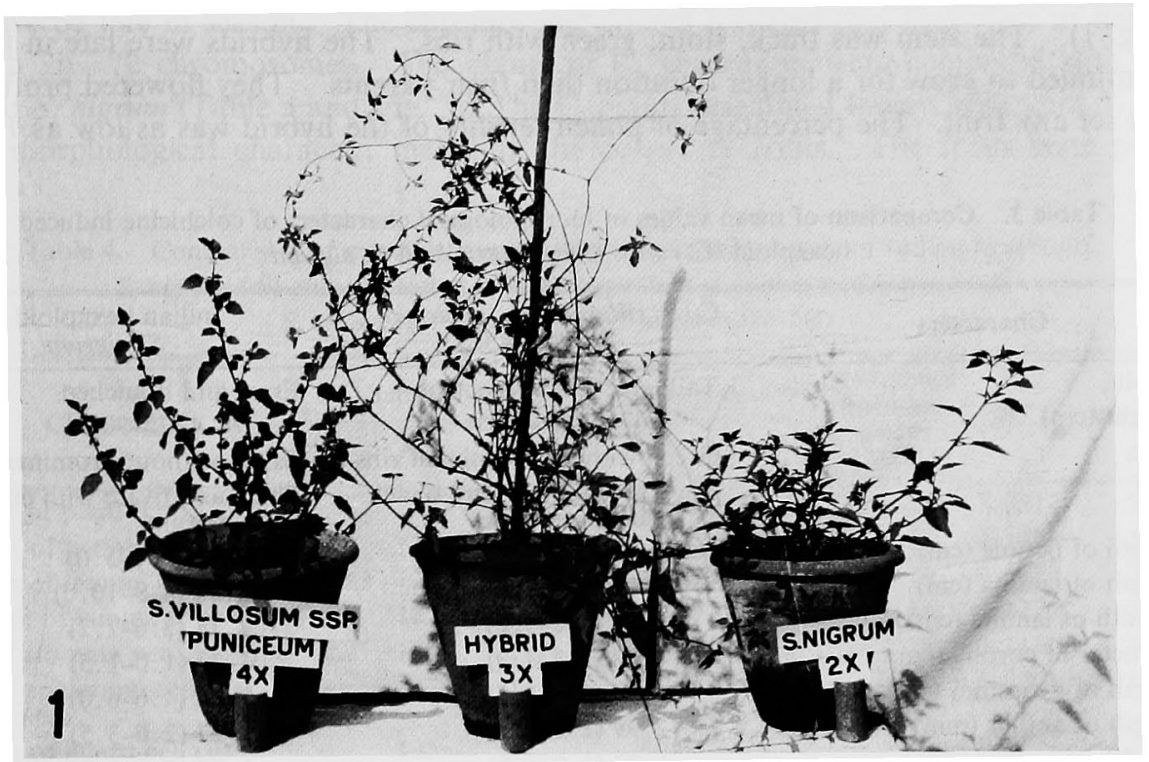

Fig. 1. Plants of $S$. villosum ssp. puniceum (left), diploid S. nigrum (right) and their $F_{1}$ hybrid (middle).

Table 2. Comparison of means of morphological characters of $S$. villosum ssp. puncieum (A) and S. americanum (B)

\begin{tabular}{|c|c|c|c|c|c|c|c|}
\hline \multirow{2}{*}{ Characters } & \multicolumn{2}{|c|}{ Sample number } & \multicolumn{2}{|c|}{ Mean value of } & \multirow{2}{*}{$\begin{array}{c}\text { Difference } \\
\text { between } \\
\text { mean } \\
\text { A-B }\end{array}$} & \multirow{2}{*}{ SED } & \multirow{2}{*}{ Remarks } \\
\hline & A & B & A & B & & & \\
\hline Height of plant $(\mathrm{cm})$ & 5 & 5 & 62.00 & 55.10 & 6.90 & 2.6735 & \\
\hline Length of petiole $(\mathrm{cm})$ & 125 & 125 & 1.88 & 2.15 & -0.27 & 0.0515 & S \\
\hline Length of lamina $(\mathrm{cm})$ & 125 & 125 & 4.07 & 5.94 & -1.87 & 0.1078 & S \\
\hline Breadth of lamina $(\mathrm{cm})$ & 125 & 125 & 2.99 & 3.13 & -0.14 & 0.0619 & $\mathbf{S}$ \\
\hline No. of stomata per unit area & 125 & 125 & 16.67 & 22.28 & -5.61 & 0.2336 & $\mathbf{S}$ \\
\hline No. of epidermal cells per unit & 125 & 125 & 35.04 & 45.96 & -10.92 & 0.3285 & $\mathbf{S}$ \\
\hline Length of guard cell $(\mu)$ & 125 & 125 & 35.01 & 33.66 & 1.35 & 0.4669 & $\mathbf{S}$ \\
\hline Breadth of guard cell $(\mu)$ & 125 & 125 & 21.99 & 23.44 & -1.5 & 0.2510 & $\mathbf{S}$ \\
\hline Length of stomatal aperture $(\mu)$ & 125 & 125 & 23.52 & 22.38 & 1.14 & 0.3930 & $\mathbf{S}$ \\
\hline Breadth of stomatal aperture $(\mu)$ & 125 & 125 & 8.02 & 8.32 & -0.30 & 0.2227 & NS \\
\hline Diameter of corolla $(\mathrm{cm})$ & 125 & 125 & 1.07 & 1.19 & -0.12 & 0.0151 & $\mathbf{S}$ \\
\hline Length of gyneocium (mm) & 125 & 125 & 4.67 & 6.22 & -1.55 & 0.0616 & $\mathbf{S}$ \\
\hline Longth of anther (mm) & 125 & 125 & 1.81 & 2.66 & -0.85 & 0.0395 & $\mathbf{S}$ \\
\hline Breadth of anther (mm) & 125 & 125 & 0.91 & 0.94 & -0.03 & 0.0830 & NS \\
\hline No. of flowers per inflorescence & 125 & 125 & 5.28 & 6.13 & -0.85 & 0.1672 & $\mathbf{S}$ \\
\hline No. of fruits per inflorescence & 125 & 125 & 4.07 & 5.43 & -1.36 & 0.1069 & $\mathbf{S}$ \\
\hline
\end{tabular}

SED $=$ Standard error of difference of means

The difference have been tested statisticaly and those indicated by the letter $S$ are found to be signiflcant at 5 per cent level and those indicated by NS are not significant. 
ssp. puniceum were pollinated out of which only 12 mature fruits with 40 seeds were obtained. All the seeds were sown but only 12 germinated and developed into mature plants. All the $F_{1}$ hybrids were at triploid level with $2 \mathrm{n}=36$ chromosomes.

\section{Morphology of $F_{1}$ hybrids}

The $F_{1}$ plants showed morphological features indicative of hybrid origin. They were tall, erect and highly branched bearing dark green ovate leaves with dentate margin (Table 1 and Fig. 1). The stem was thick, stout, green with ribs. The hybrids were late in flowering and continued to grow for a longer duration than their parents. They flowered profusely but did not set any fruit. The percentage of pollen fertility of the hybrid was as low as 1.07 (Fig.

Table 3. Comparison of mean values of morphological characters of colchicine induced hexaploid $\left(\mathrm{C}_{2}\right)$ with Indian hexaploid $S$, nigrum

\begin{tabular}{|c|c|c|}
\hline Characters & $\begin{array}{c}\mathrm{C}_{2}(S . \text { villosum ssp. puniceum } \times \\
\text { S. nigrum }(2 \mathrm{x})\end{array}$ & $\begin{array}{c}\text { Indian hexaploid } \\
\text { S. nigrum }\end{array}$ \\
\hline Habit & Tall, erect and branched & Erect and branched \\
\hline Height $(\mathrm{cm})$ & $107.6(103-115)$ & $78.4(72-90)$ \\
\hline Stem & Green without prominent ribs & Green without prominent ribs. \\
\hline Leaf & $\begin{array}{l}\text { Dark green, thick and ovate } \\
\text { with dentate margin }\end{array}$ & $\begin{array}{l}\text { Thick and ovate with entire or } \\
\text { wavy margin. }\end{array}$ \\
\hline Length of petiole $(\mathrm{cm})$ & $2.88(1.5-5.6)$ & $2.87(2.1-5.0)$ \\
\hline Length of lamina $(\mathrm{cm})$ & $7.99(5.3-10.6)$ & $6.80(4.9-10.0)$ \\
\hline Breadth of lamina $(\mathrm{cm})$ & $6.24(4.0-9.0)$ & $4.78(3.6-7.2)$ \\
\hline Diameter of corolla $(\mathrm{cm})$ & $1.58(1.3-1.9)$ & $1.22(1.0-1.5)$ \\
\hline Length of gynecium $(\mathrm{cm})$ & $5.19(5.5-6.5)$ & $5.13(4.6-6.0)$ \\
\hline Length of anther (mm) & $2.99(2.5-3.5)$ & $2.67(2.0-3.5)$ \\
\hline Breadth of anther $(\mathrm{mm})$ & $1.07(1.0-1.5)$ & $1.03(0.5-1.5)$ \\
\hline No. of flowers per inflorescence & $7.35(5-9)$ & $7.57(5-9)$ \\
\hline No. of fruit per inflorescence & $6.32(5-9)$ & $6.44(4-9)$ \\
\hline Colour of fruit & Purplish black & Purplish black \\
\hline Diameter of fruit $(\mathrm{mm})$ & $8.97(6.5-1.05)$ & $8.02(4.0-9.0)$ \\
\hline No. of seeds per fruit & $27.30(4-46)$ & $39.6(28-54)$ \\
\hline Pollen grain size $(\mu)$ & $31.68(24.64-35.2)$ & $26.29(24.64-28.16)$ \\
\hline Pollen fertility $(\%)$ & 89.16 & 92.72 \\
\hline No. of stomata per unit area & $14.61(12-20)$ & $14.42(12-16)$ \\
\hline No. of epidermal cells per unit area & $37.81(31-42)$ & $38.79(31-46)$ \\
\hline Length of guard cell $(\mu)$ & $36.76(29.92-45.76)$ & $36.12(29.92-45.76)$ \\
\hline Breadth of guard cell $(\mu)$ & $24.56(21.12-29.92)$ & $25.03(21.12-35.00)$ \\
\hline Length of stomatal aperture $(\mu)$ & $24.80(21.12-31.68)$ & $25.70(17.60-35.20)$ \\
\hline Breadth of stomatal aperture $(\mu)$ & $8.56(5.28-14.08)$ & $8.65(3.52-14.08)$ \\
\hline Gametic chromosome number $(n)$ & 36 & 36 \\
\hline
\end{tabular}

Range of values are given in parenthesis.

2) whereas in the parents, $S$. villosum ssp. puniceum and diploid $S$. nigrum, it was 98.40 and 92.58 per cent respectively. A detailed comparative account of the morphological characters of parents and their $F_{1}$ hybrids is presented in Table 1.

\section{Morphology of colchiploids}

Several axilary buds of $F_{1}$ sterile triploid hybrids were treated with different concentrations of colchicine solution for different durations. The treatment with $0.2 \%$ colchicine solution for $20 \mathrm{hrs}$ was effective and produced polyploid shoots. The meiotic study of pollen mother cells obtained from colchicine treated branches showed them to be at hexaploid level with $2 \mathrm{n}=$ 72 chromosomes. Triploid hybrids were completely sterile and did not set any fruit. The 
colchicine treated shoots of triploid hybrids showed stunted growth in the beginning and produced small, thick, dark green deformed leaves. Later on gradually normal leaves were produced. The polyploid shoots showed delayed flowering and produced flowers of larger size and light purple black fruits with viable seeds. The size of the berry was similar to that of Indian hexaploid $S$. nigrum. The pollen size of colchicine induced hexaploid $\left(\mathrm{C}_{1}\right)$ was larger than that of triploid hybrids. The induced hexaploids were pollen fertile.

The colchicine induced hexaploids $\left(\mathrm{C}_{2}\right)$ were erect, branched and showed vigorous growth. They flowered late in season. The chromosome counts revealed that they were at hexaploid level with $2 \mathrm{n}=72$ chromosomes. The plants of $\mathrm{C}_{2}$ generation were compared with Indian hexaploid $S$. nigrum (Table 3 and Fig. 7). The $\mathrm{C}_{2}$ plants resembled Indian hexaploid $S$. nigrum in their morphological character, including the colour of fruits. The fruits were purplish

Table 4. Comparison of mean values of morphological characters of Indian hexaploid $S$. nigrum (A) and colchicine induced hexaploid $\left(\mathrm{C}_{2}\right)$ obtained from cross

S. villosum $\mathrm{ssp}$. puniceum $\times$ S. nigrum $(2 \mathrm{x})(\mathrm{B})$

\begin{tabular}{|c|c|c|c|c|c|c|c|}
\hline \multirow{2}{*}{ Characters } & \multicolumn{2}{|c|}{ Sample number } & \multicolumn{2}{|c|}{ Mean value of } & \multirow{2}{*}{$\begin{array}{c}\text { Difference } \\
\text { between } \\
\text { means } \\
\text { A-B }\end{array}$} & \multirow{2}{*}{$\mathrm{SED}$} & \multirow{2}{*}{ Remarks } \\
\hline & A & B & A & $\mathrm{B}$ & & & \\
\hline Height of plant $(\mathrm{cm})$ & 5 & 5 & 78.40 & 107.60 & -29.20 & 3.9517 & $\mathbf{S}$ \\
\hline Length of petiole $(\mathrm{cm})$ & 125 & 125 & 2.87 & 2.88 & -0.01 & 0.1278 & NS \\
\hline Length of lamina $(\mathrm{cm})$ & 125 & 125 & 6.80 & 7.99 & -1.19 & 0.1623 & $\mathbf{S}$ \\
\hline Breadth of lamina $(\mathrm{cm})$ & 125 & 125 & 4.78 & 6.24 & -1.46 & 0.1326 & $\mathbf{S}$ \\
\hline No. of stomata per unit area & 125 & 125 & 14.41 & 14.61 & -0.20 & 0.2111 & NS \\
\hline $\begin{array}{l}\text { No. of epidermal cells per } \\
\text { unit area }\end{array}$ & 125 & 125 & 38.79 & 37.81 & 0.98 & 0.3701 & $\mathbf{S}$ \\
\hline Length of guard cell $(\mu)$ & 125 & 125 & 36.12 & 36.76 & -0.64 & 0.6574 & NS \\
\hline Breadth of guard cell $(\mu)$ & 125 & 125 & 25.03 & 24.56 & 0.47 & 0.4735 & NS \\
\hline Length of stomatal aperture $(\mu)$ & 125 & 125 & 25.70 & 24.80 & 0.90 & 0.5579 & NS \\
\hline Breadth of stomatal aperture $(\mu)$ & 125 & 125 & 8.65 & 8.56 & 0.09 & 0.2659 & NS \\
\hline Diameter of corolla $(\mathrm{cm})$ & 125 & 125 & 1.22 & 1.58 & -0.36 & 0.0159 & $\mathbf{S}$ \\
\hline Length of gynoecium (mm) & 125 & 125 & 5.13 & 5.19 & -0.06 & 0.0667 & NS \\
\hline Length of anther (mm) & 125 & 125 & 2.67 & 2.99 & -0.32 & 0.0501 & $\mathbf{S}$ \\
\hline Breadth of anther ( $\mathrm{mm}$ ) & 125 & 125 & 1.03 & 1.07 & -0.04 & 0.0283 & NS \\
\hline No. of flowers per inflorescence & 125 & 125 & 7.57 & 7.35 & 0.22 & 0.1468 & NS \\
\hline No. of fruits per inflorescence & 125 & 125 & 6.44 & 6.32 & 0.12 & 0.1331 & NS \\
\hline
\end{tabular}

$\mathrm{SED}=$ Standard error of difference of means

The difference have been tested statistically and those indicated by the letter $S$ are found to be signiflcant at 5 per cent level and those indicated by NS are not signiflcant.

black in Indian hexaploid $S$. nigrum as well as in synthesized hexaploid $S$. nigrum. The synthesized hexaploids were highly fertile with 89.16 per cent stainable pollen grains. Pollen fertility of Indian hexaploid $S$. nigrum was 92.72 per cent. Plants of $C_{2}$ generation resembled Indian hexaploid $S$. nigrum with respect to several features such as habit, shape of leaf, stem character and colour of berry. A detailed comparative account of the morphological characters of $\mathrm{C}_{2}$ generation and Indian hexaploid $S$. nigrum is presented in Table 3 . In general the plants of $\mathrm{C}_{2}$ generation were almost similar to Indian hexaploid $S$. nigrum in their morphological characters.

A statistical comparison of the mean values of several vegetative and floral charatcers of two populations is presented in Table 4. It is obvious from the Table that the two populations do not show significant differences in most of the morphological characters like length of petiole, number of stomata per unit area, length of guard cell, breadth of guard cell, length and 
breadth of stomatal aperture, length of gynoecium, breadth of anthers, number of flowers per inflorescence and number of fruits per inflorescence. However, the two populations differed significantly with respect to a few morphological characteres such as height of the plants, length and breadth of lamina, number of epidermal cells per unit area, diameter of corolla and length of anthers. Colchicine induced hexaploid obtained from the triploid hybrid ( $S$. villosum ssp. puniceum $\times$ diploid $S$. nigrum) showed higher mean values over Indian hexaploid $S$. nigrum in almost all the morphological characters except number of expidermal cells per unit area, breadth of guard cells, length and breadth of stomatal apertures, number of flowers per inflorescence and number of fruits per inflorescence.

Several reciprocal crosses were made between colchicine induced hexaploids and natural Indian hexaploid $S$. nigrum. The crosses were successful in both the ways and fully fertile hybrids ( $89 \%$ pollen fertility) were obtained with normal meiosis. They produced fruits with viable seeds.

Table 5. Comparison of mean chiasmata frequency per cell and per bivalent at diakinesis and metaphase I

\begin{tabular}{|c|c|c|c|c|c|c|}
\hline \multirow{2}{*}{ Materials } & \multicolumn{3}{|c|}{ Diakinesis } & \multicolumn{3}{|c|}{ Metaphase I } \\
\hline & Per cell & $\begin{array}{c}\text { Per } \\
\text { bivalent }\end{array}$ & S.E. & Per cell & $\begin{array}{c}\text { Per } \\
\text { bivalent }\end{array}$ & S.E. \\
\hline $\begin{array}{l}\text { Indian diploid } S . \text { nigrum } \\
\quad(2 \mathrm{n}=24)\end{array}$ & 19.60 & 1.63 & \pm 0.3249 & 12.96 & 1.08 & \pm 0.2076 \\
\hline $\begin{array}{l}\text { S. villosum ssp. puniceum } \\
(2 \mathrm{n}=48)\end{array}$ & 41.40 & 1.72 & \pm 0.3456 & 26.80 & 1.11 & \pm 0.2233 \\
\hline Their $F_{1}$ hybrid $(2 n=36)$ & 23.76 & 1.32 & \pm 0.4605 & 14.64 & 0.81 & \pm 0.4728 \\
\hline $\begin{array}{l}\text { Colchicin induced hexaploid } \\
\left(\mathrm{C}_{2}\right) \text { obtained from cross } \\
S \text {. villosum ssp. puniceum } \times \\
\text { diploid } S \text {. nigrum }(2 \mathrm{n}=72)\end{array}$ & 62.81 & 1.74 & \pm 0.6753 & 38.48 & 1.07 & \pm 0.5574 \\
\hline $\begin{array}{l}\text { Indian hexaploid } S . \text { nigrum } \\
\quad(2 n=72)\end{array}$ & 64.40 & 1.78 & \pm 0.5685 & 40.76 & 1.13 & \pm 0.5036 \\
\hline
\end{tabular}

S.E. $=$ Standard error

\section{Cytology}

The course of meiosis in diploid $S$. nigrum was regular and 12 bivalents were invariably seen both at diakinesis and metaphase I (Fig. 5). At diakinesis most of the bivalents were of ring type with chiasmata at both the arms of chromosomes. The chiasmata frequency per cell and per bivalent was 19.90 and 1.63 respectively (Table 5). At metaphase I mostly rod bivalents were noted. The chiasmata frequency per cell and per bivalent was 12.96 and 1.08 respectively (Table 5 ).

S. villosum ssp. puniceum showed regular meiosis with 24 bivalents both at diakinesis and metaphase I (Fig. 3). At diakinesis mostly ring bivalents were found and the chiasmata frequency per cell and per bivalent was 41.40 and 1.72 respectively (Table 5). At metaphase I, generally rod bivalents were seen and the chiasmata frequency per cell and per bivalent was 26.80 and 1.11 respectively (Table 5 ).

Triploid hybrids obtained from the cross between $S$. villosum ssp. puniceum and diploid $S$. nigrum showed a wide range of meiotic irregularities. At diakinesis and metaphase I, univalents were present together with trivalents, quadrivalents and bivalents. Most of the cells showed loose association of chromosomes. Quadrivalents were recorded in very low frequency. At diakinesis mean chromosomal associations per cell were $1.80_{\mathrm{I}}+13.22_{\mathrm{II}}+2.04_{\mathrm{III}}+0.36_{\mathrm{IV}}$. Univalents, bivalents, trivalents and quadrivalents ranged from 0 to 4,11 to 16,0 to 4 and 0 to 1 respectively. At metaphase I the pairing behaviour of chromosome was found to be extremely 

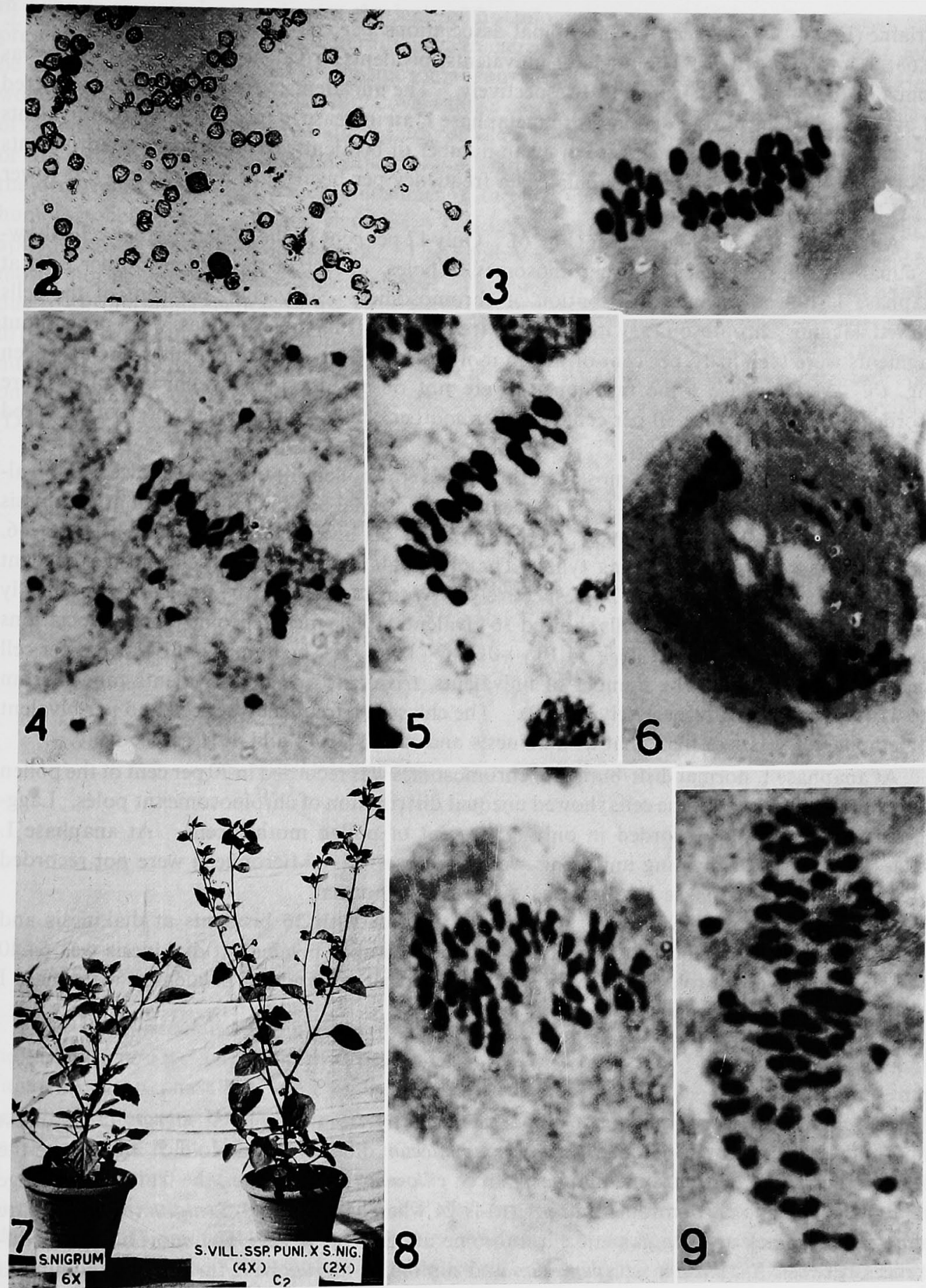

Figs. 2-9. 2, sterile pollen grains of triploid hybrid $\left(\mathrm{F}_{1}\right) . \quad 3$, metaphase I with $24 \mathrm{II}$ in $S$. villosum ssp. puniceum. 4, metaphase I with $16 \mathrm{I}+10 \mathrm{II}$ in triploid hybrid. 5, metaphase I with $12 \mathrm{II}$ in diploid $S$. nigrum. 6, anaphase I with laggards and dividing univalents in triploid hybrid. 7 , plants of Indian hexaploid $S$. nigrum (left) and synthesized hexaploid $\left(\mathrm{C}_{2}\right)$ obtaind from the cross $S$. villosum ssp. puniceum $\times$ diploid $S$. nigrum (right). 8 , metaphase I with $36 \mathrm{II}$ in Indian hexaploid S. nigrum. 9, metaphase I with in colchicine induced hexaploid $\left(C_{2}\right)$ obtained from the $F_{1}$ triploid of $S$. villosum ssp. puniceum and diploid $S$. nigrum. 
variable (Fig. 4). The mean chromosomal associations per cell at metaphase I were $9.84_{I}+$ $10.68_{I I}+1.44_{I I I}+0.12_{I V}$. The range of univalents, bivalents, trivalents and quadrivalents was from 4 to 16,7 to 15,0 to 4 and 0 to 1 respectively. The univalents were mostly found scattered all over the spindle. From diakinesis to metaphase $I$, an increase in mean number of univalents per cell with corresponding decrease in mean number of bivalents, trivalents and quadrivalents was found. The mean number of chiasmata frequency per bivalent at metaphase $I$ was lower (0.81) than that at diakinesis (1.32).

Anaphase I was highly irregular (Fig. 6). Only 12 per cent of the pollen mother cells showed equal distribution (18:18) of chromosomes at poles. Most of the pollen mother cells at anaphase I showed unequal distribution of chromosomes. Sixty eight per cent of the cells showed lagging chromosomes with varying frequencies (Fig. 6). Bridges with or without fragments were seen in 16 per cent of pollen mother cells. Dividing univalents were also seen (Fig. 6). At telophase I the micronuclei were not observed. Lagging chromosomes were recorded at anaphase II in 30 per cent of pollen mother cells. Micronuclei were not observed at telophase II.

Cytology of $\mathrm{C}_{2}$ plants was mostly normal. Several pollen mother cells showed 36 bivalents at diakinesis and metaphase I. The mean chromosomal associations per cell at diakinesis were $0.71_{I}+33.55_{I I}+0.50_{I I I}+0.66_{I V}$. The number of bivalents ranged from 27 to 36 . The bivalents were mostly of ring type. The chiasmata frequency per cell and per bivalent at diakinesis was 62.81 and 1.74 respectively. At metaphase I, the meiosis was mostly normal and a large number of cells showed 36 bivalents. The mean chromosomal associations per cell at metaphase $I$ were $1.28_{1}+34.10_{11}+0.36_{11 I}+0.40_{1 V}$. The number of bivalents per cell ranged from 29 to 36 . The number of univalents, trivalents and quadrivalents ranged from 0 to 5,0 to 2 and 0 to 1 respectively (Fig. 9). The chiasmata frequency per cell and per bivalent at metaphase I was less than that at diakinesis and it was 38.48 and 1.07 respectively.

At anaphase I, normal distribution of chromosomes was recorded in 70 per cent of the pollen mother cells. However, some cells showed unequal distribution of chromosomes at poles. Lagging chromosomes were recorded in only 8 per cent of pollen mother cells. At anaphase I. bridges, fragments or dividing univalents were not observed. Micronuclei were not recorded at telophase I and telophase II. Anaphase II was also normal.

In Indian hexaploid $S$. nigrum, meiosis was normal with 36 bivalents at diakinesis and metaphase I (Fig. 8). Chiasmata frequency per cell and per bivalent at diakinesis was 64.40 and 1.78 respectively (Table 5). Chiasmata frequency per cell and per bivalent at metaphase I was 40.76 and 1.13 respectively.

\section{Discussion}

Solanum villosum ssp. puniceum differs significantly from diploid $S$. nigrum. The most important characters by which $S$. villosum ssp. puniceum differs from diploid $S$. nigrum are the colour of berry and chromosome number. In $S$. villosum ssp. puniceum, the fruits are organge red and the gametic chromosome number (n) is 24 whereas in diploid $S$. nigrum the fruits are shining bluish black and the gametic chromosome number $(\mathrm{n})$ is 12 . The morphological differences between $S$. villosum ssp. puniceum and diploid $S$. nigrum have further been confirmed by statistical comparison of their morphological characters.

The cytology of triploid hybrids showed univalents, bivalents, trivalents and quadrivalents. They showed loose association of chromosomes in bivalents. There is considerable reduction in chiasmata per cell and per bivalent as compared to their parents. Hybrid sterility is the most effective isolating mechanism active at reproductive stage in the $F_{1}$ hybrids between $S$. villosum ssp. puniceum and diploid $S$. nigrum. The occurrence of most of the chromosomes 
in hybrids as univalents indicates the lack of homology between the parental genomes. In present investigation, the hybrid sterility is characterized by break down of meiosis which may be due to either genic factors or chromosomal causes or both (Stebbins 1947, Davis and Heywood 1967). Chromosomal sterility covers those cases in which sterility results from the lack of homology between the parental genomes, or when the parents differ in chromosome number or are distantly related ot one an other (Davis and Heywood 1967). In present investigation the occurrence of most of the chromosomes of the hybrids as univalents indicates the lack of homology between the parental genomes. This is further supported by the behaviour of hexaploids raised from triploid hybrids. The synthesized hexaploids were highly fertile with mostly normal pairing of the chromosomes. This suggests that the hybrid sterility was mostly due to chromosomal causes rather than genic (Stebbins 1950). Even if genic sterility exists in hybrids beside the chromosomal sterility, it was partly eliminated by doubling the chromosome number. This is due to the fact that the genes affecting synapsis have relatively little influence on pairing of chromosomes which are completely homologous as found in the amphidiploids (Davis and Heywood 1967).

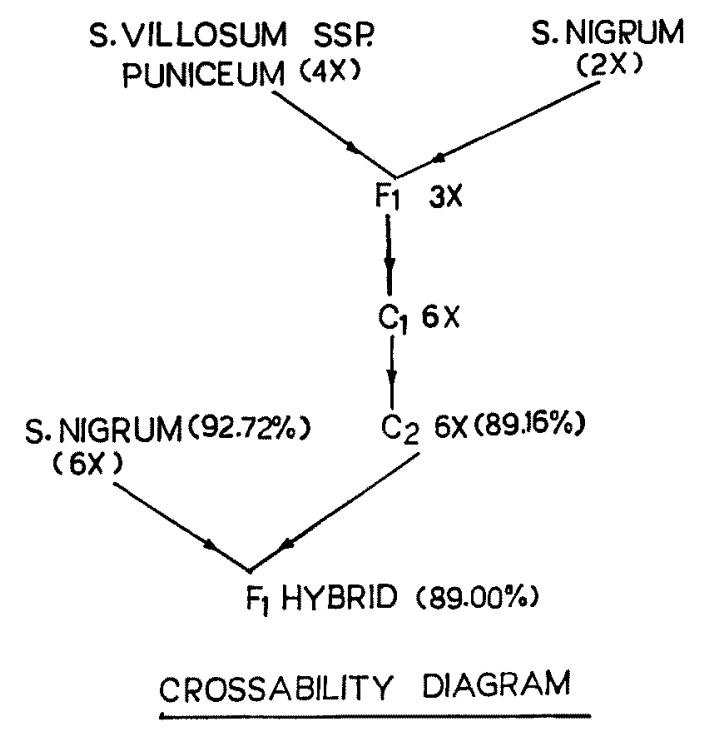

The loose associations of chromosomes with low frequency of chiasmata, as compared to the parents, besides a few multivalents and the rare occurrence of bridges with or without fragments at anaphase $I$ in some of the pollon mother cells of the hybrid may also indicate structural differences between the chromosomes of the parental genomes (Sax 1935, Kimber and Riley 1963, Riley 1966).

The $\mathrm{C}_{2}$ plants were fertile and produced a good number of viable seeds. The cytological investigation showed normal meiosis with 36 bivalents in majority of pollen mother cells. In addition to high frequency of bivalents, they showed low frequency of univalents and multivalents indicating their "raw" allopolyploid nature. The "raw" allopolypolids are the most inconsistent forms and likely to be still in very active state of evolution (Stebbins 1950). They may become progressively "diplodized" (Stebbins 1947) with increase in fertility due to mutation and rearrangments of the chromosomes (Kostoff 1938).

The comparison of the morphological characters of clolchicine induced hexaploids and Indian hexaploid $S$. nigrum showed close resemblance. The statistical analysis of several morphological characters of $C_{2}$ plants and Indian hexaploid $S$. nigrum showed that they did not 
differ significantly with respect to several characters. The chiasmata frequency per cell and per bivalent in both are nearly same. They produced purplish black fruits with a good number of viable seeds.

The production of fully fertile hybrids by crossing colchicine induced hexaploid $\left(C_{2}\right)$ with Indian hexaploid $S$. nigrum with normal meiosis and fruit setting with a large number of viable seeds, supports the closeness of genomic components between synthesized hexaploids and Indian hexaploid $S$. nigrum.

The interspecific hybridization, production of colchiploids, statistical analysis of morphological characters of colchicine induced hexaploid $\left(\mathrm{C}_{2}\right)$ and natural Indian hexaploid $S$. nigrum and their easy crossability with each other resulting fertile hybrids with viable seeds suggest that $S$. villosum ssp. puniceum (a tetraploid species) and $S$. nigrum (diploid species) have played a leading role in the origin of natural Indian hexaploid $S$. nigrum L. (see Crossability diagram).

\section{Summary}

Solanum villosum ssp. puniceum $(2 \mathrm{n}=48)$ and diploid $S$. nigrum $(2 \mathrm{n}=24)$ were crossed among themselves and the resulting triploid hybrids $(2 n=36)$ were completely pollen sterile (1.07 per cent pollen fertility). The triploid hybrids were raised to hexaploid level by giving the colchicine treatment. These synthesized hexaploids $(2 n=72)$ were compared statistically with natural Indian hexaploid $S$. nigrum and it was found that they were morphologically very much similar to each other. The cytological studies of colchiploids also revealed the formation of normally 36 bivalents like natural Indian hexaploid S. nigrum. Successful reciprocal cross was made between synthesized and natural Indian hexaploids $S$. nigrum and the resulting hybrids were fully fertile with normal meiosis. The hybrid set normal fruits with viable seeds. This supports the genomic closeness of colchicine induced hexaploids and natural Indian hexaploid $S$. nigrum L. On the basis of our findings it can be concluded that diploid $S$. nigrum and $S$. villosum ssp. puniceum may be the putative parents which have played an important role in the orgin of natural Indian hexaploid S. nigrum.

\section{References}

Bhaduri, P. N. and Ghosh, P. N. 1954. Chromosome squashes in Cereals. Stain. Technol. 29: $269-276$. D'Arcy, W. G. 1974. Solanum and its close relatives in Florida. Ann. Missouri Bot. Gard. 61: 818-867.

Davis, P. H. and Heywood, V. H. 1967. Principles of Angiosperm Taxonomy. Oliver and Boyd, Edinburg and London.

Gbile, Z. O. 1979. Solanum in Nigeria. In The Biology and Taxonomy of Solanaceae. No. 7. pp. 113-120, Linn. Soc. Acad. Press, London.

Kimber, G. and Riley, R. 1963. The relationships of the diploid progenators of hexaploid wheat. Can. J. Genet. Cytol. 5: 83-88.

Kostoff, D. 1938. Studies on polyploid plants XVIII. Cytogenetic studies on Nicotiana sylvestris $\times N$. tomentosiformis hybrids and amphidiploids and their bearing on the problem of the origin of N. tobacum. Dok. Akad. Nauk, SSSR 18: 459-462.

Magoon, M. L., Ramanujam, S. and Cooper, D. C. 1962. Cytogenetical studies in relation to the origin and differentiation of species in the genus Solanum L. Caryologia 15: 151-252.

Riley, R. 1966. Genetic and the regulation of meiotic chromosome behaviour. Sci. Progr. (London) 54: $193-207$.

Sax, K. 1935. The cytological analysis of species hybrids. Bot. Rev. 1 : 100-117.

Stebbins, G. L. 1938. Cytological characteristics associated with different growth habits in the dicotyledons. Amer. J. Bot. 25: 189-198.

- 1947. Types of polyploids: Their classification and signiflcance. Adv. Genet. 1: $403-429$.

- 1950. Variation and evolution. Science 152: 1463-1469.

Swaminathan, M. S., Magoon, M. L. and Mehra, K. L. 1954. A simple propiono-carmine PMC smear methods for plants with small chromosomes. Indian J. Genet. 14: 87-88. 